\title{
Endovascular treatment for acute traumatic thoracic aortic transection
}

\author{
Onur Ergun, M.D., ${ }^{1}$ Murat Canyiğit, M.D., ${ }^{2}$ Mete Hıdıroğlu, M.D., ${ }^{3}$ İdil Güneş Tatar, M.D., ${ }^{1}$ \\ Erdem Birgi, M.D., ${ }^{1}$ Aslıhan Küçüker, M.D., ${ }^{3}$ Emrah Uğuz, M.D., ${ }^{3}$ Hasan Ali Durmaz, M.D., ${ }^{1}$ \\ Hüseyin Çetin, M.D., ${ }^{2}$ Baki Hekimoğlu, M.D., ${ }^{1}$ Erol Şener, M.D. ${ }^{3}$
}

\author{
1Department of Radiology, Diskapi Yildirim Beyazit Training and Research Hospital, Ankara \\ ${ }^{2}$ Department of Radiology, Ataturk Training and Research Hospital, Ankara \\ ${ }^{3}$ Department of Cardiovascular Surgery, Ataturk Training and Research Hospital, Ankara
}

\begin{abstract}
BACKGROUND: This study aimed to present our experience in patients with acute traumatic thoracic aortic transection treated by endovascular stent-graft.

METHODS: From October $20 \mathrm{II}$ to October 20I4, eleven patients were brought to our hospitals after suffering motor vehicle accident or fall from height. Computed tomography revealed acute traumatic transection of the thoracic aorta at the aortic isthmus just distal to the left subclavian artery in nine patients, at the middle or distal thoracic aorta in two, and both aortic isthmus and middle thoracic aorta in one. Endovascular technique was preferred as the treatment modality. All patients, except one, were treated within twelve hours of diagnosis.
\end{abstract}

RESULTS: Deployment of stent-grafts was successful in all cases. The stent-grafts were oversized between $10 \%$ and $20 \%$. The origin of left subclavian artery was covered with stent-graft in six patients to achieve adequate proximal landing zone. In two of them, carotico-subclavian bypass and periscope graft placement were applied to maintain subclavian artery blood flow. There were no procedure related deaths, paraplegia or ischemic complications. A patient with cardiac arrest, on whom cardiopulmonary resuscitation and transient aortic balloon occlusion within the aorta were applied in the angiography suit died at the postoperative twelve hours. Mean hospital stay after procedures was I4.8 days (range, 4-60 days). Mean follow-up time of ten patients was 16.6 months (range, I-36 months).

CONCLUSION: Our study supports that thoracic endovascular aortic stenting for acute transection is promising in terms of shortand mid-term results similar to other studies in the literature.

Key words: Aortic rupture; aortic stent-graft; aortic transection; endovascular treatment.

\section{INTRODUCTION}

Traumatic aortic transection is a rare but often fatal injury that generally occurs due to motor vehicle accidents, which is also associated with other life-threatening injuries. Mortality rates are extremely high, and most patients die before arriving at the hospital. ${ }^{[1]}$ The mechanism of injury

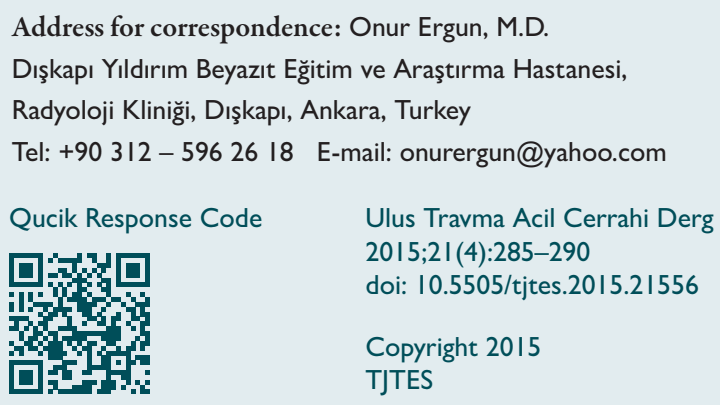

after blunt thoracic trauma has been shown as high-speed deceleration in the anterior-posterior and lateral directions resulting in torsion, bending, shearing and increase in intravascular pressure. Depending on all these factors, transverse tears occur mostly at the level of the aortic isthmus and also at the aortic root and diaphragm. ${ }^{[2]}$ Current diagnosis of traumatic aortic transection is mainly made by contrast-enhanced computed tomography (CT). ${ }^{[2]}$ Treatment options include open thoracic surgery and endovascular repair.

This study aimed to present our treatment experience and short- and mid-term results in patients with acute traumatic thoracic aortic transection treated by endovascular stent-graft.

\section{MATERIALS AND METHODS}

From October $20 \mathrm{II}$ to October 20I4, eleven patients (eight 
male and three female) were brought to our hospitals after suffering motor vehicle accident or fall from height. Mean age of the patients was 46.7 years (range, 15-66). All of the cases first underwent CT imaging of the thorax and abdomen. CT revealed acute traumatic transection of the thoracic aorta at the aortic isthmus just distal to the left subclavian artery in nine patients, at the middle or distal thoracic aorta in two, and both aortic isthmus and middle thoracic aorta in one. Moreover, CT demonstrated at least two or more associated injuries such as pulmonary contusion, pleural effusion, pneumothorax, pericardial effusion, left-sided hemothorax, rib fractures, fractured pelvis, intraabdominal hemorrhage, and thoracolumbar vertebra compression fractures.

Endovascular technique was preferred as the treatment modality. Full informed written consent was obtained from all patients or patients' first-degree relatives, and they were informed about the risks of the procedure. Ten of the eleven patients were treated within the twelve hours of diagnosis. One patient with a history of traffic accident ten days prior was admitted to hospital with severe backache. This patient was treated on that admittance. In all patients, arterial access for stent-grafts was provided by right-sided femoral cut-down under general anesthesia. In an urgent status like cardiothoracic shock, an aortic balloon was transiently dilated within the aorta at the just distal the subclavian artery by using the left femoral artery.

All of the procedures were performed under systematical heparinization with $3000 \mathrm{IU}$ heparin, which is a lower dose than in elective endovascular stenting cases as recommended. [3] Diagnostic digital subtraction angiography (DSA) was performed to establish the anatomy of the aortic arch and confirm the location of the transection in all patients. Arterial access for diagnostic catheters was achieved from left common femoral artery in eight patients and from left brachial artery in three. Both vertebral arteries were initially evaluated in patients who had a transection line with less than $15 \mathrm{~mm}$ distance to the left subclavian artery in the CT examination and the left subclavian artery needed to be closed. If the right vertebral artery was hypoplasic or atretic, preprocedural surgical carotico-subclavian bypass or revascularization of the left subclavian artery with parallel grafting during the endovascular procedure was performed. All patients were treated with thoracic aortic stent-grafts. None of our patients received prophylactic spinal drainage, which is not recommended due to the reasons such as proximal location of the injury, limited coverage of the thoracic aorta, and the risk of epidural hematoma. ${ }^{[3]}$

The patients were discharged with $300 \mathrm{mg}$ acetylsalicylic acid medication alone. Follow-up examinations were performed with CT angiography carried out before discharge from the hospital, and at three, six and twelve months postoperatively and yearly thereafter.

\section{RESULTS}

Deployment of stent-grafts was successful in all cases (technical success: 100\%). The mean aortic diameter was $24.09 \mathrm{~mm}$ (range, 19-28 mm). The mean stent-graft diameter was 27.63 $\mathrm{mm}$ (range, 22-32 mm). The stent-grafts were oversized between $10 \%$ and $20 \%$. Patient data and stent-graft details were demonstrated in Table I.

The origin of left subclavian artery was covered with stentgraft in six patients to achieve adequate proximal landing zone. While left carotid-subclavian bypass was performed in one of the two patients with right vertebral artery hypoplasia in the angiography suit, periscope graft technique for subclavian artery blood supply was applied in the other patient during the procedure. A $9 \times 150 \mathrm{~mm}$ heparin coated self-expandable covered stent (Viabahn, WL Gore and Associates Inc. Flagstaff, Ariz) was used as a periscope graft.

In one patient with pelvic fractures, selective internal iliac embolization was performed to stop active bleeding from the internal iliac artery branches by using multiple coils and Amplatzer Vascular Plug (AGA Medical Corporation, Birmingham, UK) just after the aortic stent-graft procedure.

There were no procedure related deaths, left upper extremity ischemic complications, cerebrovascular events, or paraplegia in any of the patients. A patient with cardiac arrest on whom cardiopulmonary resuscitation and transient aortic balloon occlusion within the aorta at the just distal of the subclavian artery were applied in the angiography suit was deceased at the postoperative twelve hours (Figs. Ia-d).

Postoperative CT images confirmed technical success in exclusion of the transection without any types of endoleak. Mean hospital stay after procedures was I4.8 days (range, 4-60 days).

Mean follow-up time of ten patients was 16.6 months (range I-36 months). The stent-grafts were patent with no evidence of endoleak, stent-graft collapse or migration. Besides, carotico-subclavian bypass graft and periscope graft were also patent at the postoperative first year CT angiography, respectively.

\section{DISCUSSION}

Traumatic transection of the aorta is often a fatal injury that arises after high-energy blunt trauma with a mortality rate of $86.2 \%$ outside the hospital. Aortic transection is the second most common cause of death following head injury (intracranial hemorrhage) with a rate of occurrence between $13 \%$ and $20 \%$ after blunt trauma. ${ }^{[3,4]}$ Most patients with acute traumatic aortic transection show no evidence of aortic injury until hemodynamic instability occurs. ${ }^{[2]}$ In high impact motor vehicle accidents, rapid deceleration causes aortic arch injury mostly at the level of the isthmus. ${ }^{[5]}$ Patients with aortic injury also have concomitant traumas. It is important to evaluate 
Table I. Patient data and stent-graft details

\begin{tabular}{|c|c|c|c|c|c|c|c|c|c|}
\hline No & Sex & $\begin{array}{c}\text { Age } \\
\text { (year) }\end{array}$ & $\begin{array}{l}\text { Mechanism } \\
\text { of injury }\end{array}$ & $\begin{array}{l}\text { Location of } \\
\text { transection }\end{array}$ & $\begin{array}{c}\text { Distance } \\
\text { from left } \\
\text { subclavian } \\
\text { artery } \\
(\mathrm{mm})\end{array}$ & Stent-graft & $\begin{array}{l}\text { Aortic } \\
\text { diameter } \\
(\mathbf{m m})\end{array}$ & $\begin{array}{l}\text { Graft size } \\
(\mathbf{m m})\end{array}$ & $\begin{array}{c}\text { Follow } \\
\text {-up } \\
\text { (month) }\end{array}$ \\
\hline I & Male & 49 & $\begin{array}{c}\text { Motor vehicle } \\
\text { accident }\end{array}$ & Aortic isthmus & 8 & Cook-Zenith & 27 & $32 \times 32 \times 160$ & 18 \\
\hline 2 & Male & 43 & Fall from height & Aortic isthmus & 10 & Medtronic-Talent & 27 & $32 \times 32 \times 100$ & 8 \\
\hline 3 & Male & 54 & $\begin{array}{c}\text { Motor vehicle } \\
\text { accident }\end{array}$ & $\begin{array}{c}\text { Distal thoracic } \\
\text { aorta }\end{array}$ & 90 & Medtronic-Talent & 26 & $30 \times 30 \times 100$ & 7 \\
\hline 4 & Female & 15 & Fall from height & Aortic isthmus & 0 & Medtronic- Vailant & 20 & $22 \times 22 \times 112$ & 36 \\
\hline 5 & Male & 42 & $\begin{array}{c}\text { Motor vehicle } \\
\text { accident }\end{array}$ & Aortic isthmus & 20 & Cook-Zenith & 21 & $24 \times 24 \times 80$ & 36 \\
\hline 6 & Female & 45 & $\begin{array}{c}\text { Motor vehicle } \\
\text { accident }\end{array}$ & Aortic isthmus & 18 & Gore- TAG & 19 & $22 \times 22 \times 100$ & 24 \\
\hline 7 & Male & 48 & Fall from height & Aortic isthmus & 10 & Cook-Zenith & 25 & $28 \times 28 \times 140$ & 12 \\
\hline 8 & Male & 48 & $\begin{array}{c}\text { Motor vehicle } \\
\text { accident }\end{array}$ & $\begin{array}{l}\text { Middle thoracic } \\
\text { aorta }\end{array}$ & 40 & Cook-Zenith & 28 & $32 \times 32 \times 140$ & Exitus \\
\hline 9 & Male & 66 & $\begin{array}{c}\text { Motor vehicle } \\
\text { accident }\end{array}$ & Aortic isthmus & 8 & Cook-Zenith & 25 & $28 \times 28 \times 140$ & 12 \\
\hline 10 & Female & 43 & $\begin{array}{c}\text { Motor vehicle } \\
\text { accident }\end{array}$ & Aortic isthmus & 3 & Cook-Zenith & 22 & $26 \times 26 \times 134$ & 12 \\
\hline 11 & Male & 61 & Fall from height & $\begin{array}{c}\text { Both aortic isthmus } \\
\text { and middle } \\
\text { thoracic aorta }\end{array}$ & 7 & Cook-Zenith & 25 & $28 \times 28 \times 140$ & 1 \\
\hline
\end{tabular}

whether hemodynamic instability is aorta-related or not. In case of acute massive mediastinal hematoma, active bleeding or left sided hemothorax; endovascular approach must be performed immediately. Otherwise, non-aorta-related life threatening injuries must be treated first and endovascular repair is suggested to be performed within 24 hours. ${ }^{[4]}$

While open surgical repair has been performed as conventional treatment of traumatic aortic transection for years, endovascular stents have started to be used with low rates of morbidity and mortality by the rapid development of aortic stent-grafts in the last two decades. ${ }^{[1]}$ The first clinical experience of endovascular stent-grafting in abdominal aortic aneurysms was described in 199I by Parodi et al. ${ }^{[6]}$ It is now a well-established method of treatment as an alternative to open surgery. There are some clear advantages of endovascular treatment over open surgery, including avoidance of left thoracotomy, single lung ventilation, aortic cross-clamping and cardiopulmonary bypass, reduced surgery time and reduced blood loss. ${ }^{[2,4]}$ Mortality rates of endovascular treatment are between $0 \%$ and $20 \%$, which is more favorable when compared to open surgery. After open surgical repair of traumatic aortic injuries, 30-day mortality rates are between $15 \%$ and $50 \%{ }^{[2]}$ The risks of death and spinal cord ischemia are significantly lower in all age groups after endovascular treatment compared with surgery. ${ }^{[3]}$ There were no procedure related deaths in our patient group. Our 30-day mortality rate was $9.1 \%$.

Paraplegia is the most serious complication of treatment and is seen postoperatively with an incidence of $2.3 \%$ to $25.5 \%$. [4] The low risk of paraplegia is an advantage of the endovascular procedure when compared with open surgery. ${ }^{[4]}$ Other short-term complications of endovascular treatment include stroke, access-site complications, stent collapse and recurrent laryngeal nerve damage, with morbidity ranging $3 \%$ to $36 \% .{ }^{[2]}$ In a literature review, the incidence of stroke or transient ischemic attack has been reported as 1.2\%. ${ }^{[7]}$ We didn't observe paraplegia or any ischemic complications in our patient group. In the same review, the incidence of early and late endoleak after endovascular treatment has been reported as $4.2 \%$ and $0.9 \%$, respectively. ${ }^{[7]}$ Our technical success was $100 \%$ without any types of endoleak.

Due to technical success and lower early and late complication rates, endovascular stenting for aortic transection 

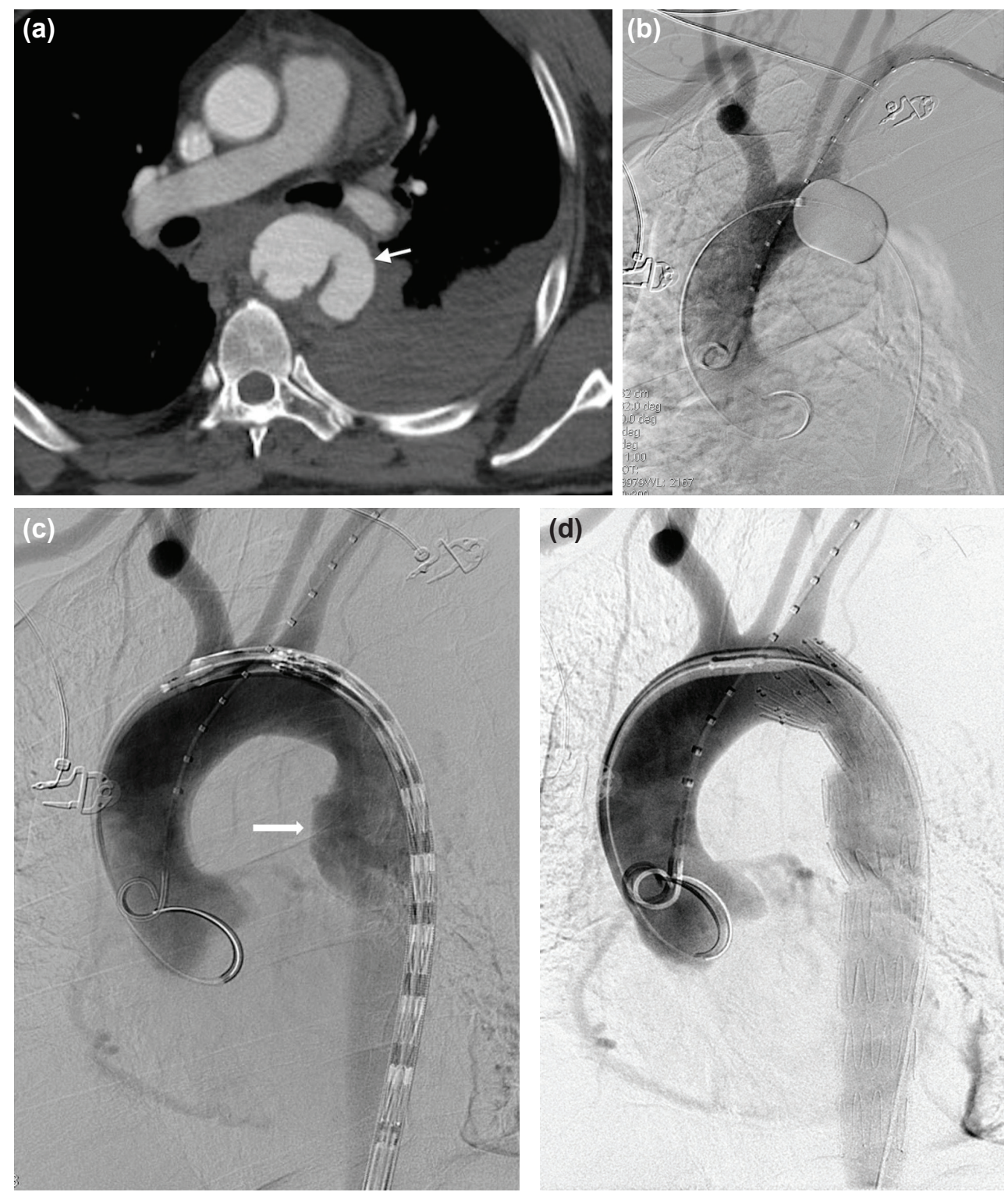

Figure 1. (a-d) Axial thoracic computed tomography angiography image (a) shows a pseudoaneurysm from the anterolateral aspect of the proximal thoracic aorta (white arrow) compatible with aortic transection in a motor vehicle accident's patient. Cardiac arrest was developed in the angiography suit, and cardiopulmonary resuscitation and transient aortic balloon occlusion (b) within the aorta at the just distal of the subclavian artery were applied. Aortogram obtained just after the balloon deflation and stent-graft insertion (c) reveals a pseudoaneurysm at the proximal thoracic aorta (white arrow). Aortogram after stent-graft deployment (d) demonstrated successful exclusion of the pseudoaneursym.

has replaced open surgical repair as the primary treatment modality in many centers. Endovascular aortic stenting may reduce mortality and paraplegia rates by half compared with open surgery, whichmakes endovascular treatment the firstline therapy for blunt thoracic aortic trauma. ${ }^{[7]}$

Rates of stent-graft collapse after endovascular treatment has been reported between $0.03 \%$ and $10 \%$ in the literature. ${ }^{[4]}$ Excessive oversizing of the stent-graft and acute angle of the aortic arch are the factors that can lead to stent collapse. ${ }^{[4]}$ Caudal migration of stent-graft can also occur with an in- cidence of $1 \%$ to $2.8 \% .^{[8]}$ Together with tortuous seal zone anatomy, excessive oversizing is also a predisposing factor for caudal migration ${ }^{[8]}$ Accordingly, oversizing is an important problem for endovascular treatment due to lack of small-caliber stent-grafts for use in young patients with usually smaller aorta diameters. We didn't observe any stent collapse or caudal migration of the stent-graft in our limited patient group in the follow up.

Aortic transections occur mostly at the level of the aortic isthmus. Therefore, it is usually difficult to find enough space 
from the origin of the left subclavian artery for proximal landing zone of stent-graft. If there is not adequate proximal landing zone, left subclavian artery may be sacrificed. At that point, the dominancy of vertebral arteries becomes important. If the right vertebral artery is atretic or hypoplastic without intact posterior communicating arteries, surgical carotid-subclavian bypass should be performed. ${ }^{[3]}$ Also recently, endovascular revascularization procedures such as modified chimney and periscope graft techniques have been introduced as an alternative to surgery. ${ }^{[9]}$ Extra-anatomical bypass surgery is a well established method with high patency rates, but long-term durability of these new endovascular techniques is not clearly known yet. ${ }^{[10]}$ We had to cover the origin of the left subclavian artery in six of our patients to achieve adequate proximal landing zone. In two patients, right vertebral artery was hypoplastic. Surgical left carotid-subclavian bypass was performed in one of the patients in the angiography suit and endovascular periscope graft technique for left subclavian artery blood supply was applied in the other patient during the endovascular procedure. These patients did not develop any ischemic complications.

Covering of the left subclavian artery may also lead to higher incidence of upper extremity ischemia and stroke. Left upper extremity symptoms have occurred in up to $15.8 \%$ of patients, in which left subclavian artery was covered during thoracic endovascular repair, but intervention was required in only $5.8 \%$ of patients in one study. ${ }^{\left[{ }^{11}\right]}$ In addition, Leong Tan et al. have reported that they covered the left subclavian artery with the stent-graft in five of their six patients during endovascular stenting for traumatic thoracic aortic injury and none of the patients had any upper extremity ischemic complications or cerebrovascular events. However, authors stated that in all five patients, right vertebral artery was dominant. ${ }^{[12]}$ We also didn't observe any ischemic complications in four patients with dominant right vertebral artery, in whom the left subclavian artery was covered with stent-graft.

Our study has some limitations including the limited number of patients and lack of long-term follow-up of our patients.

Open surgical repair for aortic transection is associated with considerable rate of perioperative morbidity and mortality. Endovascular treatment has replaced open surgical repair as the primary treatment modality in many centers. Yet, there are no randomized controlled trials comparing open surgery with endovascular treatment for aortic transection. Similar to our study, retrospective studies indicate that short and mid-term results of thoracic endovascular aortic stenting for transection are promising, but prospective long-term studies are mandatory to assess durability of the stent-grafts since the majority of the patients are at a young age.

\section{Conflict of interest: None declared.}

\section{REFERENCES}

1. Chung-Yu Lo, Chun-Che Shih. Endovascular Treatment for Traumatic Aortic Rupture. Acta Cardiol Sin 2008;24:97-9.

2. Steenburg SD, Ravenel JG, Ikonomidis JS, Schönholz C, Reeves S. Acute traumatic aortic injury: imaging evaluation and management. Radiology 2008;248:748-62. CrossRef

3. Lee WA, Matsumura JS, Mitchell RS, Farber MA, Greenberg RK, Azizzadeh A, et al. Endovascular repair of traumatic thoracic aortic injury: clinical practice guidelines of the Society for Vascular Surgery. J Vasc Surg 2011;53:187-92. CrossRef

4. Chalvatzoulis E, Megalopoulos A, Trellopoulos G, Ananiadou O, Papoulidis P, Kemanetzi I, et al. Endovascular repair of traumatic aortic transection. Interact Cardiovasc Thorac Surg 2010;11:238-42. CrossRef

5. Asmat A, Tan L, Caleb MG, Lee CN, Robless PA. Endovascular management of traumatic thoracic aortic transection. Asian Cardiovasc Thorac Ann 2009;17:458-61. CrossRef

6. Parodi JC, Palmaz JC, Barone HD. Transfemoral intraluminal graft implantation for abdominal aortic aneurysms. Ann Vasc Surg 1991;5:491-9.

7. Hoffer EK, Forauer AR, Silas AM, Gemery JM. Endovascular stent-graft or open surgical repair for blunt thoracic aortic trauma: systematic review. J Vasc Interv Radiol 2008;19:1153-64. CrossRef

8. Wang GJ, Fairman RM. Endovascular repair of the thoracic aorta. Semin Intervent Radiol 2009;26:17-24. CrossRef

9. Lachat M, Mayer D, Pfammatter T, Criado FJ, Rancic Z, Larzon T, et al. Periscope endograft technique to revascularize the left subclavian artery during thoracic endovascular aortic repair. J Endovasc Ther 2013;20:728-34. CrossRef

10. Kucuker A, Hidiroglu M, Cetin L. The results of carotid-subclavian bypass in a single institute. Damar Cer Derg 2013;22:285-91. CrossRef

11. Riesenman PJ, Farber MA, Mendes RR, Marston WA, Fulton JJ, Keagy BA. Coverage of the left subclavian artery during thoracic endovascular aortic repair. J Vasc Surg 2007;45:90-5. CrossRef

12. Leong Tan GW, Pek CH, Wong D, Punamiya S, Chiu MT, Appasamy $\mathrm{V}$, et al. Management of blunt traumatic thoracic aorta injuries with endovascular stent-grafts in a tertiary hospital in an urban Asian city. Ann Vasc Surg 2011;25:605-11. CrossRef 
ORİJINAL ÇALIŞMA - ÖZET

\section{Akut travmatik torasik aort transeksiyonunda endovasküler tedavi \\ Dr. Onur Ergun,, ${ }^{1}$ Dr. Murat Canyiğit, ${ }^{2}$ Dr. Mete Hıdıroğlu, ${ }^{3}$ Dr. İdil Güneş Tatar, ${ }^{1}$ Dr. Erdem Birgi, ${ }^{1}$ Dr. Aslıhan Küçüker, ${ }^{3}$ Dr. Emrah Uğuz, ${ }^{3}$ Dr. Hasan Ali Durmaz, ${ }^{1}$ Dr. Hüseyin Çetin, ${ }^{2}$ Dr. Baki Hekimoğlu, ${ }^{1}$ Dr. Erol Şener ${ }^{3}$}

\section{Dışkapı Yıldırım Beyazıt Eğitim ve Araştırma Hastanesi, Radyoloji Kliniği, Ankara \\ ${ }^{2}$ Atatürk Eğitim ve Araştırma Hastanesi, Radyoloji Kliniği, Ankara}

${ }^{3}$ Atatürk Eğitim ve Araştırma Hastanesi, Kalp ve Damar Cerrahisi Kliniği, Ankara

AMAÇ: Biz bu çalışmada endovasküler stent-greft ile tedavi ettiğimiz akut travmatik torasik aort transeksiyonu hastalarındaki deneyimimizi sunmayı amaçladık.

GEREÇ VE YÖNTEM: Eylül 201 I ile Eylül 2014 tarihleri arasında trafik kazası veya yüksekten düşme sonrası hastanelerimize getirilen on bir hasta çalışmaya dahil edildi. Bilgisayarlı tomografi ile dokuz hastada aortik istmusta, iki hastada orta-distal torasik aortada, bir hastada ise hem aortik istmusta hem de orta torasik aortada akut aortik transeksiyon görüldü. Tedavi yöntemi olarak endovasküler yöntem tercih edildi. Bir hasta haricindeki tüm hastalar tanı sonrası 12 saat içerisinde tedavi edildi.

BULGULAR: Stent-greftler tüm olgularda başarıyla yerine yerleştirildi. Stent-greftler hedef damar çapına oranla \% 10 ila \%20 oranında daha geniş çapta kullanıldı. Altı hastada stentin tutunması için yeterli proksimal alan sağlanması için sol subklavyen arterin orijini stent-greft ile kapatıldı. Bu hastaların ikisinde sol subklavyen arterdeki akımın devam etmesi için cerrahi karotiko-subklavyen by-pass ve endovasküler periskop stent-greft yöntemleri kullanıldı. İşleme bağlı ölüm, parapleji veya iskemik bulgu hiçbir hastada izlenmedi. Anjiyografi odasında kardiyopulmoner resüsitasyon ve aortada geçici balon oklüzyonu uygulanan kardiyak arrestli bir hasta işlem sonrası 12. saatte hayatını kaybetti. Hastaların operasyon sonrası ortalama hastanede kalış süresi I 4.8 gün (4 ila 60 gün) olarak hesaplandı. On hastanın ortalama takip süresi I6.6 ay idi (I ila 36 ay).

TARTIŞMA: Bizim çalışmamızda elde ettiğimiz sonuçlar literatürdeki diğer çalışmalara benzer şekilde akut aort transeksiyonunda endovasküler stent-greft tedavisinin kısa ve orta vadede başarılı ve umut verici olduğunu desteklemektedir.

Anahtar sözcükler: Aort ruptürü; aortik stent-greft; aort transeksiyonu; endovasküler tedavi.

Ulus Travma Acil Cerrahi Derg 2015;2I (4):285-290 doi: 10.5505/tjtes.20I5.21556 